\title{
MARGINALISASI BUDAYA (STUDI PADA PRANATA SOSIAL MASYARAKAT MUSLIM SUKU KOKODA KOTA SORONG)
}

\author{
Andi Ahriani \\ andiahriani@gmail.com \\ Andi Agustang \\ andi.agustang@unm.ac.id \\ Andi Asrifan \\ andiasrifan@gmail.com
}

\begin{abstract}
Latar Belakang
Menurut Hirschman, paradigma pembangunan selalu menganggap pertumbuhan dan pemerataan akan selalu dinikmati masyarakat sampai ke lapisan yang paling bawah melalui proses tetesan ke bawah (trickle down effect). Namun, dari pengalaman pembangunan dalam tiga dasawarsa (1940-1970), realita yang terjadi adalah rakyat di lapisan bawah tidak menikmati kucuran hasil pembangunan tersebut, seperti yang diharapkan. (Mardikanto, 2013: 14) Harapan ideal pada proses pembangunan masyarakat (People Centered Development) yang menempatkan masyarakat sebagai pusat perhatian sekaligus sebagai pelaku utama pembangunan, seringkali tidak tercapai. pada kenyataannya masih banyak kelompok masyarakat atau suku yang terpinggirkan yang tampak jelas sangat kesulitan untuk ikut berpartisipasi dalam proses pembangunan tersebut. Tidak jarang suara mereka disisihkan. Institusi-institusi lokal yang ada pun mengalami keterbatasan dalam hal menyuarakan aspirasi rakyatnya sendiri.
\end{abstract}

Masyarakat marginal adalah mereka yang tidak dapat menyesuaikan dan melibatkan diri dalam proses pembangunan, masyarakat yang terpinggirkan, mereka berada pada posisi yang relatif tidak berdaya dan secara politis mereka dianggap tidak penting dibandingkan dengan masyarakat lainnya. (Argo Trikomo, 1999). Dari penjelasan ini bisa dikatakan bahwa masyarakat marginal adalah mereka yang tidak memiliki kemampuan untuk menyesuaikan dan melibatkan diri dalam proses pembangunan. Marginalisasi menghasilkan orang-orang atau individu (atau pun kelompok baru yang) marginal; yaitu mereka yang terpasung dalam ketidakpastian psikologis di antara dua (atau lebih) komunitas masyarakat/sosial; sehingga mereka penuh dengan ketidakmampuan mengekspresikan diri serta terbatas (karena dibatasi) daya jangkaunya.

Melalui pembangunan yang tidak dilengkapi dengan perencanaan yang detail dan disusun tanpa mendengarkan aspirasi dari masyarakat, maka ketika itulah masyarakat mulai terpinggirkan oleh pembangunan. Akan timbul rasa 
termarginalisasi dan ketakberdayaan terhadap sebuah desain perubahan yang berhubungan langsung dengan hidup dan nasib mereka tetapi mereka tidak dilibatkan. Mereka seakan dialienasikan dari perubahan yang justru menjadikan mereka sebagai obyeknya. (Darmawan Salman, 2005:9)

Kota Sorong dihuni beberapa masyarakat pendatang dan tentunya masyarakat asli Papua. Masyarakat asli Papua ini terdiri dari ratusan bahkan lebih suku-suku yang berbeda. Meskipun mereka sama-sama suku asli Papua namun kondisi masing-masing suku ini amatlah berbeda. Yang paling mencolok adalah Suku Kokoda. Suku Kokoda awalnya bermukim di sekitar area bandara namun karena alasan perluasan area bandara tersebut sehingga mereka menjadi korban penggusuran dan direlokasi ke tempat yang sangat tidak layak. Mereka direlokasi ke lahan gambut yang tentunya mendatangkan banyak masalah baru. Misalnya kesulitan akses air bersih dan munculnya berbagai macam penyakit.

Secara umum, Papua sangat terkenal dengan kekayaan sumber daya alam yang melimpah. Keberlimpahan sumber daya alam tersebut bertolak belakang dengan kehidupan masyarakatnya. Lebih dari $80 \%$ masyarakat Papua tergolong miskin atau sangat miskin. (Stepanus Malak, 2015:50-51). Kondisi yang hampir sama dengan wilayah Papua Barat, khususnya di kota Sorong. Akan tetapi, pada kenyataannya sebagian besar masyarakat Muslim Kokoda yang bermukim di KM.8 Kota Sorong masih dikenal dengan kelompok masyarakat miskin dan sangat memprihatinkan.

Beberapa penelitian mengatakan bahwa Kemiskinan yang terjadi pada masyarakat Muslim Kokoda dipengaruhi oleh dua faktor, yaitu: karakteristik masyarakat yang pemalas dan penghasilan yang rendah dan tidak menentu. (Abdul Rahman, dkk:33). Dalam hal pekerjaan, masyarakat Kokoda hanya fokus pada aspek pertanian atau pekerjaan paruh waktu. Sehingga, membuat mereka hanya sebagai produsen bahan mentah dan sebaliknya menjadi konsumen barang jadi. Selain itu, sifat pemalas tersebut diperparah dengan kultur yang suka melakukan perbuatan menyimpang, seperti minum-minuman keras, berjudi, sex bebas dan budaya hidup serba hedonistik. Kondisi lain yang dialami oleh masyarakat Kokoda adalah kurangnya kesadaran dalam hal pendidikan (pengangguran - ketidakmerataan pendapatan - kemiskinan), stereotype gender atau marjinalisasi perempuan.( Akramunnisa, 2013:2).

Kondisi pada masyarakat Kokoda ini menjadi akibat dari proses pembangunan yang terdistribusi tidak adil. Menurut Darmawan Salman (2005:10), ketika hasilhasil pembangunan tidak terdistribusi secara adil dan merata dalam masyarakat maka ketika itu pula dampak kesenjangan social-ekonomi akan terjadi. Pembangunan menyebabkan masyarakat akan terpolarisasi atas kaya dan yang miskin, pembangunan akan memacu kecemburuan sosial. Sebagai contoh, sebuah bangunan kawasan industri hanya akan memberikan kemanfaatan kepada sebagian saja namun sebaliknya akan meminggirkan masyarakat lain. 
Karena telah terjadi polarisasi miskin dan kaya sehingga mereka sebagai sesama suku asli papuapun juga terjadi kesenjangan. Terdapat beberapa suku asli yang memiliki status sosial ekonomi yang mapan serta memiliki minat pendidikan yang tinggi. Terbukti banyak dari mereka melanjutkan kuliah ke Jawa bahkan sampai ke luar negeri. Kondisi ini tentu sangat berbeda jauh dengan apa yang dialami oleh masyarakat Muslim Kokoda. Posisi mereka yang menjadi subkultur mengkonstruksi kehidupan mereka berada pada kondisi masyarakat yang dikenal sekarang yaitu masayarakat Kokoda yang memiliki sifat fatalisme, malas dan lemahnya achievement motivation, kurang berorientasi ke depan menjadikan mereka menjadi suku yang terkebelakang dibandingkan dengan suku asli Papua lainnya.

Selain itu, jauhnya masyarakat Kokoda dari akses sumber kekuasaan dan penguasaan sumberdaya alam membuat mereka berada pada posisi yang tidak berdaya. Mereka tidak memiliki posisi tawar sehingga sangat susah untuk ikut berkontribusi dalam panggung pendidikan dan panggung politik. Masyarakat Kokoda ini tidak memiliki satupun wakil pada kursi pemerintah maupun pemerintahan. Inilah yang kemudian semakin mempersulit posisi masyarakat muslim Kokoda sehingga suku-suku yang lain menganggap suku kokoda suku yang tertinggal karena tidak mampu ikut berkontribusi atau ikut bersaing mengikuti arus perubahan masyarakat modern yang massive dan kompleks.

Apabila situasi kemiskinan telah terlalu lama mencekam suatu kelompok, maka akan terbentuk sikap dan perilaku manusianya, sehingga terbentuklah nilai -nilai khas yang erat hubungannya dengan masalah kemiskinan dan usaha manusia untuk mengadaptasikan diri telah berlangsung secara turun temurun dan seringkali sudah terstruktur dan masive. (Soetomo, 2015: 197). Pengaruh negatif dari pembagunan yang tidak memiliki perencanaan yang matang bukan hanya melemahkan masyarakat pada aspek ekonomi tetapi juga sudah menggrogoti aspek institusi atau pranata sosial masyarakat. Pengaruhnya sudah sampai pada dekonstruksi nilai, makna dan kesakralan dari komunitas adat itu sendiri.

Menurut Darmawan Salman (2005: 10), ketika sebuah industri dibangun di tengah komunitas lokal, maka tunggulah "matinya"nilai dan norma budaya masyarakat lokal tersebut dan akan terpinggirkan, secara perlahan penganutnya akan mengikuti nilai dan norma budaya akan dikonstruksi oleh kompleks industri tersebut. Contoh, pudarnya penghargaan kepada kepala adat atau ketua suku mereka. Pada awalnya, ketika ingin memutuskan sesuatu maka harus diputuskan oleh kepala suku, tetapi sekarang nilai itu sudah bergeser dengan nilai-nilai individualistik yang lebih mementingkan kepentingan pribadi masing-masing. Termasuk suara politik mereka sudah tidak bersatu lagi sesuai dengan arahan kepala suku tetapi masyarakat sudah menuntut hak demokrasi. Dengan sendirinya melunturkan pranata atau adat istiadat yang selama ini telah dibangun secara turun temurun. 
Selain itu, masyarakat Suku Kokoda juga memiliki nilai-nilai budaya yang sangat berarti dan dijunjung tinggi, yang kemudian bisa dijadikan sebagai modal sosial dalam peningkatan kualitas hidup masyarakat. Seperti, tenggang rasa yang tinggi, kebersamaan dan rela berkorban, susah senang dipikul bersama, memelihara dan mempertahankan tradisi atau warisan leluhur serta menjunjung tinggi pluralisme. (Firman Sujadi, dkk, 2015:56). Akan tetapi, pada kenyataannya nilainilai tersebut mulai luntur dan seakan tidak mampu lagi menjadi pranata untuk membantu mereka keluar dari belenggu kemiskinan dan keterbelakangan.

\section{Masalah Penelitian}

Berdasarkan uraian dari latar belakang di atas, ditemukan bahwa kehidupan masyarakat Muslim Kokoda masih berada pada kondisi yang tidak mampu melepaskan diri dari perangkap kemiskinan dan keterbelakangan. Bahkan sampai hari ini mereka belum mampu bersaing secara sosial ekonomi dengan para pendatang bahkan dengan suku asli Papua lainnya. Pada kondisi ini, masyarakat diposisikan hanya sekadar sebagai obyek yang tentunya dapat mengakibatkan kecilnya peluang untuk aktualisasi diri dan mengembangkan kapasitas. Beberapa bentuknya pada masyarakat Suku Kokoda adalah tidak ada akses dalam pengambilan keputusan untuk menentukan tindakan bersama, akses terhadap sumberdaya, peluang dan informasi yang sempit dan tidak ada akses terhadap berbagai bentuk pelayanan. Realitas inilah yang mengakibatkan kehidupan sosial masyarakat Muslim Kokoda cenderung lebih rendah dari lapisan lain. Bahkan lebih dari itu, mereka merasa bahwa mereka tereliminasi dalam kehidupan bersama, seolah-oleh mereka menjadi warga kelas dua.

Kondisi tersebut di atas yang dianulir menyebabkan masyarakat Kokoda menjadi suku yang termarginalkan karena mereka dikonstruksi untuk semakin menjauh dari kekuasaan dan sumberdaya. Masyarakat semakin terisolasi dalam kondisi yang tidak menguntungkan. Mereka seakan terpasung dalam ketidakpastian psikologis di antara suku yang lain. Sehingga mereka ada pada posisi ketidakmampuan untuk mengekspresikan diri serta keterbatasan dalam daya jangkau terhadap power (kekuasaan) dan resources atau kekayaan sumberdaya di daerah mereka sendiri digantikan dengan tatanan baru yang bahkan tidak dimengerti oleh masyarakat yang masih asli dan memiliki pranata sosial yang fungsional dalam masyarakatnya.

Ketika ada intervensi pembangunan, maka Mekanisme struktural yang dibangun oleh penguasa dengan segala kekhasannya telah mengatur keberlangsungan hidup masyarakat adat sehingga terjadi perbenturan nilai budaya dan struktur kelembagaan. Oleh sebab itu masyarakat adat yang sangat dikorbankan karena telah dikonsepsi untuk menjadi semakin tergantung kepada penguasa. Di aspek lain, secara kultural, sengaja atau tidak sengaja nila-nilai budaya lokal digerus terus menerus dan dikontestasi sehingga masyarakat adat dalam hal ini masyarakat suku Kokoda menjadi kehilangan jati dirinya. Karena mereka seakan dihegemoni dengan pandangan materialistik yang mendewakan kelimpahan dan kemewahan dunia sebagai satu-satunya tujuan hidup yang membahagiakan yang 
membuat mereka lupa bahwa mereka adalah satu, meraka adalah saudara sebagai suku asli Papua.

Untuk menjawab beberapa permasalahan pokok tersebut di atas, penulis membuat pertanyaan sebagai berikut:

1. Mengapa masyarakat Suku Kokoda mengalami marginalisasi budaya

2. Bagaimana pranata sosial Masyarakat Suku Kokoda

3. Bagaimana perubahan pranata sosial masyarakat Suku Kokoda

Maksud dan Tujuan Penelitian

Penelitian ini bermaksud untuk memahami, melakukan interpretasi dan menganalisis berbagai hal berikut:

1. Adanya kecendrungan ciri-ciri pada masyarakat Suku Kokoda menjadi sub kultur dari kultur lain yang notabene sebagai sesame suku asli Papua. Mereka dikonstruksi untuk semakin menjauh dari kekuasaan dan sumberdaya. Masyarakat semakin terisolasi dalam kondisi yang tidak menguntungkan. Mereka seakan terpasung dalam ketidakpastian psikologis di antara suku yang lain sehingga tidak tercapai kondisi kesetaraan.

2. Masyarakat Suku Kokoda memiliki nilai-nilai sosial budaya yang memungkinkan dijadikan sebagai modal sosial untuk merubah kehidupan mereka ke arah yang sama dengan suku yang lain. Namun pranata tersebut tidak begitu berperan dalam mendukung masyarakat untuk mencapai kesetaraan.

3. secara kultural, sengaja atau tidak sengaja nila-nilai budaya lokal dan pranata sosial budaa digerus terus menerus dan dikontestasi sehingga pranata sosial masyarakat suku Kokoda mengalami perubahan dan menjadi kehilangan jati dirinya. Karena mereka seakan dihegemoni dengan pandangan materialistik yang mendewakan kelimpahan dan kemewahan dunia sebagai satu-satunya tujuan hidup yang membahagiakan yang membuat mereka lupa bahwa mereka adalah satu, meraka adalah saudara sebagai suku asli Papua.

Adapun tujuan dari penelitian ini adalah untuk menemukan dan merumuskan syarat-syarat yang diperlukan sebagai solusi teoritik dan dapat dijadikan sebagai acuan untuk membantu masyarakat Suku Kokoda mampu bersaing dengan sesame suku asli papua bahkan dengan suku pendatang yang berorientasi pada kemajuan, kemandirian dengan sistem pranata sosial yang semakin solid dan tangguh di tengah masifnya persaingan hidup dan kemajuan zaman.

\section{Tinjauan Pustaka}

Masyarakat marginal adalah mereka yang tidak dapat menyesuaikan dan melibatkan diri dalam proses pembangunan, masyarakat yang terpinggirkan, mereka berada pada posisi yang relatif tidak berdaya dan secara politis mereka dianggap tidak penting dibandingkan dengan masyarakat lainnya. (Argo Trikomo, 1999). Dari penjelasan ini bisa dikatakan bahwa masyarakat marginal adalah mereka yang tidak memiliki kemampuan untuk menyesuaikan dan melibatkan diri dalam proses pembangunan. Marginalisasi menghasilkan orang-orang atau individu (atau pun kelompok baru yang) marginal; yaitu mereka yang 
terpasung dalam ketidakpastian psikologis di antara dua (atau lebih) komunitas masyarakat/sosial; sehingga mereka penuh dengan ketidakmampuan mengekspresikan diri serta terbatas (karena dibatasi) daya jangkaunya.

Perubahan pola dominasi akan terwujud apabila telah terjadi perubahan dalam penguasaan sumberdaya baik sumber daya otoritatif maupun alokatif. Hal itu disebabkan karena penguasaan sumberdaya menentukan siapa yang lebih besar pengaruh dan posisi tawarnya dalam proses relasi sosial yang terjadi. (Soetomo, 2013: 185). ketika Alokasi sumberdaya dimanifestasi dalam bentuk akses kewenangan semua lapisan masyarakat dalam proses pengambilan keputusan maka akan mengakibatkan peningkatan penguasaan oleh lapisan marginal.

Dalam penelitian ini, penulis telah melakukan penelusuran terhadap beberapa riset terdahulu. Riset tersebut tentunya ada keterkaitan ataupun perbedaan dengan obyek penelitian yang akan dikaji dalam penelitian ini. Hal ini dilakukan untuk melihat perbedaan antara hasil penelitian yang sudah ada dengan obyek yang penulis teliti atau menghindari adanya kesamaan dengan obyek penelitian sebelumnya. Adapun judul-judul penelitian sebelumnya yang membahas mengenai masyarakat Kokoda khususnya dan marginalisasi pada umumnya adalah sebagai berikut:

Penelitian yang pertama adalah Muhammad Huzain dengan judul "Peran Perempuan Dalam Rumah Tangga Miskin Muslim Kokoda" dalam penelitian ini membahas tentang kontribusi seorang ibu rumah tangga dalam membantu suami mereka untuk memenuhi kebutuhan sehari-hari. Lebih lanjut penelitian ini menggambarkan kondisi masyarakat Kokoda saat ini, yang hidup miskin dan sangat memprihatinkan. Kemiskinan tersebut dipengaruhi oleh dua faktor, yaitu: karakteristik masyarakat yang pemalas dan penghasilan yang rendah dan tidak menentu. Penghasilan mereka hanya bergantung dari alam, seperti bagi mereka yang nelayan pergi menangkap ikan dan yang di daratan setiap pekan masuk ke hutan untuk mencari kayu kemudian dijual di kota.

Penalitian kedua yang dilakukan oleh Akramunnisa dengan judul "Konstruksi Relasi Gender Masyarakat Papua". Penelitian ini membahas tentang bagaimana relasi gender yang terbangun dalam rumah tangga masyarakat Kokoda. Penelitian ini bermaksud untuk mengungkapkan relasi yang seimbang antara peran laki-laki dan peran perempuan dalam rumah tangga, khususnya pada suku Kokoda yang bermukim di kota Sorong Papua Barat. Bagi perempuan pribumi Papua, stereotype terhadap perempuan tidak semestinya disematkan kepada mereka terlebih lagi secara u|mum perempuan Papua dikenal termasuk pekerja keras dengan etos kerja yang tinggi, tidak mudah berpangku tangan, tekun dan ulet bekerja guna mensejahterakan kehidupan yang mandiri. Banyak kajian yang menunjukkan bahwa perempuan Papua adalah pekerja keras. Etos kerja yang tinggi dilatarbelakangi oleh kesadaran sosiokultural masyarakatnya dan dukungan dari berbagai sistem sosial yang ada, serta sebagai refleksi kesadaran akan pentingnya masa depan yang lebih baik. 
Penelitian yang ketiga adalah Abd. Rahman dengan judul "Kemiskinan Dalam Perspektif perempuan Kokoda". Adapun fokus yang diteliti dalam penelitian ini adalah tantangan peran aktif perempuan Suku Kokoda-Papua dalam pengentasan kemiskinan pada rumah tangga miskin. walaupun bumi Papua kaya dengan potensi alam, tetapi alam yang kaya itu tak bisa membuat masyarakatnya yang miskin menjadi lebih kaya secara ekonomi. Kota Sorong salah satu daerah di Papua Barat yang kaya dengan sumber daya alamnya namun juga termasuk salah satu daerah yang memiliki warga miskin terbanyak.

Penelitian keempat terkait marginalisasi yaitu, oleh Yunindyawati dengan judul Marjinalisasi Pedesaan Akibat Relasi Kuasa Lokal dan supralokal. Pada penelitian ini mengkaji mengenai perkembangan desa sebagai sebuah transformasi yang dinamis yang sering mengalami marginalisasi atau memperoleh Kontrol dari kekuasaan Negara. Pembanguna menjadikan desa sebagai sebagai basis kekuasaan. Sebelum adanya relasi dan intervensi Negara dan pasar, desa sangat merdeka karena mereka memiliki struktur sosial, ekonomi, politik yang khas yang disepakati secara bersama. Setelah berinteraksi ternyata desa kehilangan otoritas dan kemerdekaanya dan tergantung kepada kekuasaan Negara.

Penelitian kelima, oleh Fuad Muchlis Dkk dengan judul Sejarah Marginalisasi Orang Rimba Bukit Dua Belas di Era Orde Baru. Pada penelitian ini mendeskripsikan potret kehidupan orang rimba Bukit Dua Belas di Era Orde Baru menjelaskan bahwa perubahan identitas budaya dan pola hidup orang Rimba tidak terlepas dari perubahan bentang alam yang terus terdegradasi akibat kebijakan Negara melalui pemberian izin HPH.HTI dan perkebunan kelapa sawit serta program transmigrasi menjadi factor utama marginalisasi orang Rimba.

Dari beberapa penelitian yang ditemukan sebelumnya hanya berkisar mengenai komdisi marginal atau proses marginalisasi secara umum. Belum ada yang lebih spesifik meneliti terkait marginalisasi budaya antar sesame suku papua. Penelitian lainnya terkait Suku Kokoda, belum ada yang secara gamblang mengeksplisitkan konidisi marginalisasi yang mereka alami hanya sampai pada kesimpulan penelitian bahwa masyarakat Muskim Kokoda berada pada kondisi miskin dan terkebelakang disbanding dengan sesame suku asli Papua lainnya pun dengan suku pendatang.

\section{Kerangka Pemikiran}

Untuk menganalisis persoalan marginalisasi pada masyarakat Muslim Suku Kokoda dilihat dari aspek kekuasaan yang diperkenalkan oleh Fucault dan dekonstruksi sistem oleh Derrida.

Menurut Foucault (Bagus Wirawan, 2014: 257), kekuasaan bukan milik sekelompok kapitalis saja. Akan tetapi Fucault memandang bahwa semua golongan memiliki potensi untuk mendapatkan kekuasaan. Yang dibutuhkan untuk mendapatkan kekuasaan adalah staregi bukan kekerasan ataupun 
penindasan. Strategi tersebut berlangsung dimana-mana yang di dalamnya termuat serangkaian sistem, aturan, aturan dan regulasi. Bagi Fucault, suatu kekuatan akan selalu ada selama sebuah relasi dan interaksi terus berkembang. Pada proses ini selalu ada pihak yang mendominasi dan didominasi. Bahkan di setiap tempat kekuasaan itu selalu ada dan menunggu untuk ditempati.

Pada perspektif Fucault di atas, peneliti menyimpulkan bahwa kondisi marginalisasi budaya yang terjadi pada masyarakat Muslim Kokoda terjadi karena akibat dari sebuah struktur kekuasaan yang dihasilkan dari relasi antar suku-suku Asli Papua. Dari interkasi antar suku inilah menurut Peter Leonard, akan menghasilkan dua kelompok yaitu kelompok pertama yang relatif marginal terhadap tatanan sosial, dan kelompok kedua adalah golongan mereka yang secara tidak sadar telah dimarginalkan (Macmillan, 1984:180).

Pada kondisi ini, masyarakat diposisikan hanya sekadar sebagai obyek yang tentunya dapat mengakibatkan kecilnya peluang untuk aktualisasi diri dan mengembangkan kapasitas. Beberapa bentuknya pada masyarakat Suku Kokoda adalah tidak ada akses dalam pengambilan keputusan untuk menentukan tindakan bersama, akses terhadap sumberdaya, peluang dan informasi yang sempit dan tidak ada akses terhadap berbagai bentuk pelayanan. Realitas inilah yang mengakibatkan kehidupan sosial masyarakat Muslim Kokoda cenderung lebih rendah dari lapisan lain. Bahkan lebih dari itu, mereka merasa bahwa mereka tereliminasi dalam kehidupan bersama, seolah-oleh mereka menjadi warga kelas dua.

Dalam perspektif budaya, marginalisasi berarti menempatkan atau menggeser sebuah budaya atau suku ke pinggiran. Marginalisasi merupakan proses pengabaian hak-hak yang seharusnya didapatkan oleh pihak yang termarginalkan.

Menurut Fakih, (2014) proses marginalisasi sama saja dengan proses pemiskinan. Hal ini dikarenakan tidak diberinya kesempatan kepada pihak yang termarginalkan untuk mengembangkan dirinya. Demikian juga yang dialami oleh masyarakat Suku Kokoda, ketika proses marginalisasi ini terjadi pada sebuah suku budaya. Suku Kokoda merupakan Suku yang dipinggirkan dari suku-suku asli Papua lainnya yang ada di kota Sorong.

Menurut Derrida, pada era modern sekarang ini dibutuhkan dekonstruksi sistem termasuk pada sistem kekuasaan. Menurutnya, perlu dilakukan pembongkaran atau dekonstruksi terhadap konsep yang dianggap kurang benar atau kurang tepat maupun kurang relevan pada zamannya. Derrida memandang bahwa, struktur selalu mempertentangkan dua hal dan dari dua hal tersebut selalu ada pihak yang disingkirkan dan ada yang diistimewakan. Dengan demikian, pola berpikir terstruktur seperti ini berarti ada dominasi. Oleh karena itu perlu adanya pembongkaran kembali terhadap pola pikir terstruktur tersebut. ((Wirawan, 2014: 284). 
Derrida tidak menyangkal adanya struktur pertentangan (oposisi) tetapi ia menolak adanya hierarki prioritas. Sebab setiap pemberian prioritas sama dengan penindasan (dominasi) oleh yang satu terhadap yang lain. Menurut Derrida (Wirawan, 2014:285), ada itu tidak mungkin dimengerti dalam dirinya secara sempurna. la membutuhkan segala sesuatunya untuk menjelaskan dirinya.

Oleh karenanya menurut Derrida, lokus realitas sosial yang dianggap otonom adalah agency. Dengan maksud mengadakan dekonstruksi pada struktur opositif. la ingin membongkar struktur yang dapat melahirkan prioritas, dominasi, dan penindasan lainnya. Tanpa ada individu struktur tidak terbentuk. Semua individu dalam struktur tersebut sama kedudukannya, tidak ada prioritas tertentu, tidak ada perbedaandan tidak ada dominasi.

Terkait dengan penelitian ini, yang dimaksudkan dengan agen di sini adalah masyarakat Muslim Suku Kokoda. Yang mana dimaksudkan bahwa Suku Kokoda adalah bagian dari suku-suku yang lain. Begitupun dengan suku asli papua lainnya juga adalah bagian integral dengan suku Kokoda. Sesuai dengan teori Derrida, dekonstruksi struktur kekuasaan ingin membongkar struktur yang dapat melahirkan marginalisasi atau ketidakadilan. Dengan begitu diharapkan terjadi kesetaraan atau posisi yang sama antar seluruh suku Papua yang ada di Kota Sorong. 


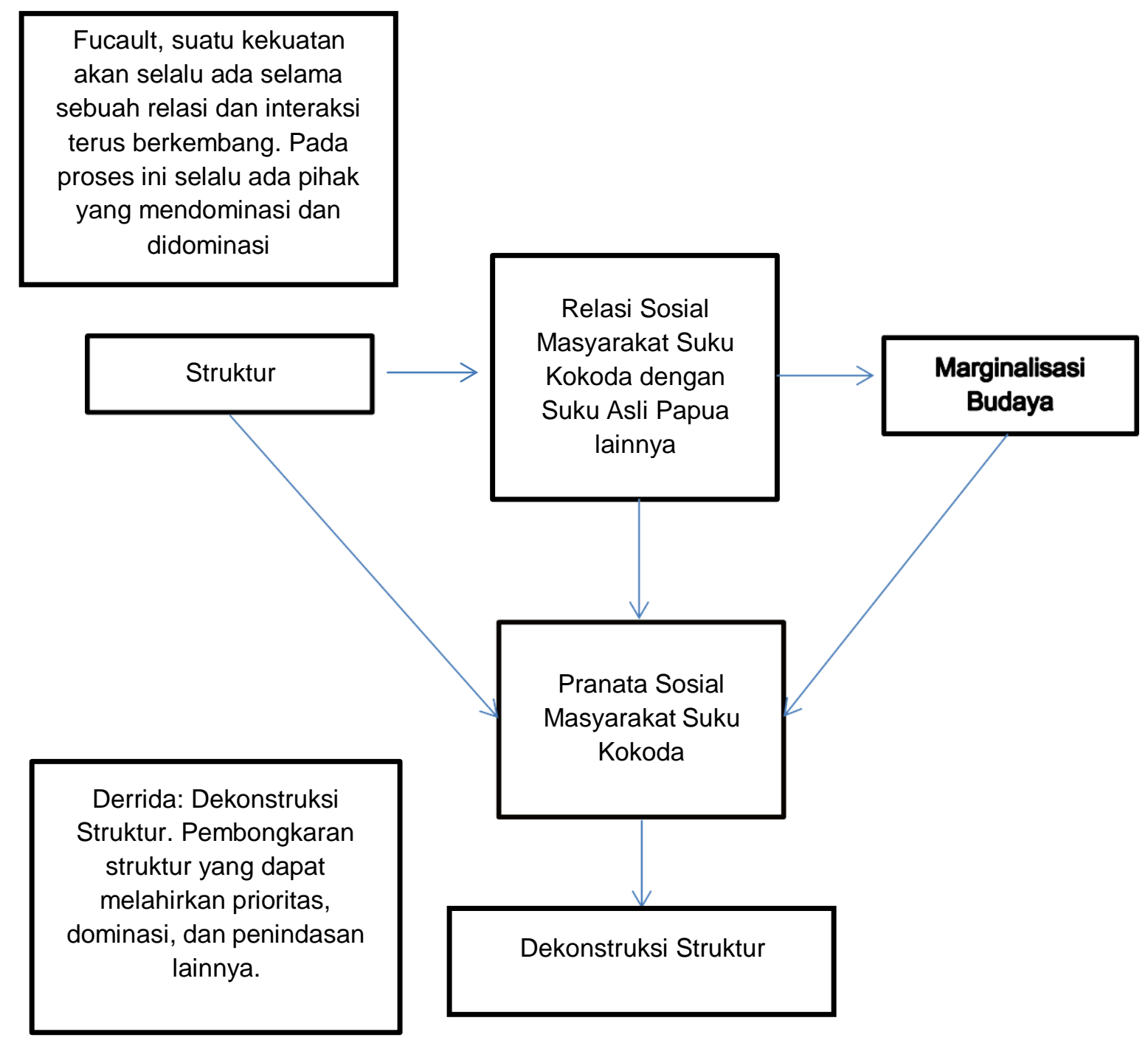

\section{Metode Penelitian}

1. Jenis Penelitian

Jenis penelitian yang digunakan dalam penelitian ini adalah jenis penelitian deskriptif kualitatif. Yaitu suatu jenis penelitian yang berusaha mendapatkan pengetahuan yang dasarnya pada data-data empiris. Menurut Sugiyono, prosedur operasional pendekatan ini adalah mulai dari penentuan masalah penelitian, pengumpulan data, penyusunan konsep dan analisis dari orangorang atau perilaku yang diamati.

2. Data dan Sumber Data Jenis data dalam penelitian ini adalah data kualitatif yang diperoleh melalui Teknik Pengamatan, Teknik Wawancara dan Teknik Dokumentasi.

Adapun sumber data penelitian dibagi dua, yaitu:

a. Data Primer 
Data Primer diperoleh dari observasi langsung ke lapangan serta hasil wawancara dengan informan menyangkut objek yang diteliti dan disesuaikan dengan kebutuhan. Dalam penelitian ini peneliti memilih informan berdasarkan pertimbangan representasi dari masyarakat dan pemerintahan atau stakeholder yang bersangkutan. yaitu: keterwakilan perempuan, generasi pemuda, tokoh masyarakat, tokoh agama serta masyarakat umum.

b. Data Sekunder

Data sekunder diperoleh dari dokumen-dokumen penelitian sebelumnya serta data program pemerintah yang terkait dengan Program Pemberdayaan.

\section{Analisis Data}

Teknik analisis yang akan digunakan dalam penelitian ini yaitu dengan menelaah semua data-data yang diperoleh dari berbagai sumber, wawancara langsung dengan informan, serta pengamatan di lapangan. Setelah itu melakukan penyusunan strategi dengan mengkalisifikasikan data.

\section{DAFTAR PUSTAKA}

Agustang, Andi. (2021). Filosofi Research Dalam Upaya Pengembangan Ilmu. OSF Preprints. https://doi.org/10.31219/osf.io/9n6za

Agustang, A. D. M. P., \& Agustang, A. (2022a). Dinamika Putus Sekolah Di Kalangan Pekerja Anak di Kota Makassar. In OSF Preprints (Issue 10.31219/osf.io/ucbz4). OSF Preprints.

Agustang, A. D. M. P., \& Agustang, A. (2022b). Makna Pembangunan. In OSF Preprints (Issue 10.31219/osf.io/rbz6c). OSF Preprints.

Agustang, A, \& Oruh, S. (2017). Factors affecting of heropnam of mental disorders in Dadi Regional Hospital in South Sulawesi Province. Man in India, 97(11), 233-244.

Agustang, Andi, \& Adam, A. (2020). Institutional Failures in The World of Education in Schools For Children Victims of Parents. Asian Journal of Social Sciences \& Humanities, 9(2), 18-26.

Agustang, Andi, Adam, A., \& Upe, A. (2021). Online Learning and Distortion of Character Education in the Covid-19 Pandemic Era. Management.

Agustang, Andi, Mithhar, \& Agustang, A. (2022). Distorsi Pendidikan Karakter Siswa Dalam Pendidikan Jarak Jauh Pada Era Pandemi Covid-19 Di Kabupaten Majene, Indonesia. OSF Preprints. https://doi.org/10.31219/osf.io/whszd

Agustang, Andi, \& Oruh, S. (2021). Kesejahteraan Psikologis (Studi Pada Dewasa Madya yang Belum Menikah di Kota Makassar). OSF Preprints.

Agustang, Andi, Oruh, S., Agustang, A., \& Agustang, A. D. M. P. (2021). SOCIAL DETERMINANTS OF COMMUNITY HEALTH WITH THE EVENT OF DIABETES MELLITUS (Study of Health Sociology in Makassar City). OSF Preprints. https://doi.org/10.31219/osf.io/4qvxf

Agustang, K. (2019). Tradisi Khatam Qur'an sebagai Upaya Perwujudan Pendidikan KarekterIslami di Kota Ternate Maluku Utara. Foramadiahi, 11(1), 34-50.

Ahriani, A., Agustang, A., Adam, A., \& Upe, A. (2020). The Multiple Roles of Women in Poor. Journal of Advanced Research in Dynamical and Control Systems - JARDCS.

Akbar, H., \& Agustang, A. (2021). The Sociocultural Determinants of Schistosomiasis Cases at Lindu Plateau, Sigi District, Indonesia. PROCEEDINGS 3nd INTERNATIONAL CONFERENCE ON HANDLING NON-COMMUNICABLE DISEASES (3ndICHNCDs) "The Role of Health Care Providers on Handling Non-Communicable Disease Through Innovative Technology in the Research.” Tuesday and Wednesday, 23rd - 24th Nov, 1(1), 150-158. 
Akbar, H., Oruh, S., \& Agustang, A. (2021). Indeks Prediktif Kejadian Demam Berdarah Dengue (DBD) Berbasis Perilaku Sosial Masyarakat Di Kabupaten Indramayu. Jurnal Kesehatan, 14(2 SE-), 76-82. https://doi.org/10.32763/juke.v14i2.289

Al Yakin, A., \& Agustang, A. (2020). Selebrifikasi dan Elektabilitas; Menakar Respon Publik. OSF Preprints.

Alamsyah, A., Agustang, A., Adam, A., \& Alim, A. (2021). Partisipasi Teritorial Masyarakat Lingkar Tambang Morosi Kabupaten Konawe. Seminar Nasional LP2M UNM.

Alim, A., Badwi, A., \& Amalia, A. (2021). Quality Analysis of Liquid Waste at The Blood Transfusion Unit of South Sulawesi. The Indonesian Journal of Public Health, 16(1), 32. https://doi.org/10.20473/ijph.v16i1.2021.32-42

Allolangi, R. P., \& Agustang, A. (2022). Principal's Strategy in Overcoming Teaching and Learning Problems at SMAN 9 Tana Toraja. Jurnal Etika Demokrasi, 7(1), 175-184.

Amran, N. G., \& Agustang, A. (2020). Implementasi Kurikulum 2013 Dalam Peningkatan Kompetensi Psikomotorik Dan Afektif Siswa. Phinisi Integration Review, 3(2), 179-184.

Andini, N. F., \& Agustang, A. (2022). Sistem Perjodohan Anak di Kecamatan Manggala Kota Makassar. Pinisi Journal of Sociology Education Review, 1(2), 192-198.

Andriana, A., Agustang, A., \& Idkhan, A. M. (2022). Faktor-Faktor Yang Mendukung Dan Menghambat Kinerja Aparatur Perempuan Di Kecamatan Bontomarannu Kabupaten Gowa. JISIP (Jurnal Ilmu Sosial Dan Pendidikan), 6(1).

Andriana, Agustang, A., Idkhan, A. M., \& Hasriadi. (2021). Daya Tanggap Pelayanan Unit Gawat Darurat di Puskesmas Sarjo Kabupaten Pasangkayu . Journal Governance and Politics (JGP), I(2 SE-Articles). https://e-journal.iyb.ac.id/index.php/jgp/article/view/201

Ardiansyah, A. A., \& Agustang, A. (2018). Mahasiswi Berkeluarga di Fakultas Ilmu Sosial Universitas Negeri Makassar. JURNAL SOSIALISASI, 19-23.

Arham, M., \& Agustang, A. (2022). Perubahan Media Bermain dan Pergeseran Gaya Hidup Anak di Lingkungan Bulu Kecamatan Mattiro Bulu Kabupaten Pinrang. OSF Preprints.

Arifin, L., Agustang, A., \& Idkhan, A. M. (2021). Analysis of the Challenges of Motor Vehicle Tax Revenue at the Technical Service Unit Office Revenue. Jurnal Ad'ministrare, 8(1), 427-434.

Aris, Agustang, A., \& Idkhan, A. M. (2021). Efektifitas Pelayanan Aparatur Sipil Dalam Meningkatkan Pelayanan Publik. Journal Governance and Politics (JGP), 1(2 SE-Articles). https://jurnal.iyb.ac.id/index.php/jgp/article/view/208

Aris, M., Agustang, A., \& Muhammad Idkhan, A. (2021). Implementation of Entrepreneurial Government in Makassar City Government. Jurnal Ilmiah Ilmu Administrasi Publik, 11(2), 482486.

Arisal, A., Agustang, A., \& Syukur, M. (2020). Diskriminasi Sosial Anak Penderita Kusta di Kota Makassar. Phinisi Integration Review, 3(2), 297-304.

Arpin, \& Agustang, A. (2022). Kesesuaian Pengangkatan Pejabat Struktural Pada Pemerintah Kota Makassar. JISIP (Jurnal Ilmu Sosial Dan Pendidikan), 6(1), 2093-2105.

Arpin, Agustang, A., \& Idkhan, A. M. (2021). Pengaruh Penerapan Model Dicovery Learning Terhadap Hasil Belajar Siswa Pada Mata Pelajaran IPA SD Inpres Tamalanrea V Kota Makassar. Journal Governance and Politics (JGP), $1(2$ SE-Articles). https://ejournal.iyb.ac.id/index.php/jgp/article/view/204

Arpin, Agustang, A., \& Idkhan, M. (2022). Analisis Terhadap Kebijakan Pembinaan Anak Jalanan Di Kota Makassar. JISIP (Jurnal Ilmu Sosial Dan Pendidikan), 6(1), 2066-2076.

Arwin, Agustang, A., Ihsan, A., \& Suhaeb, F. (2015). Poverty and Modernization in Bajo Fishing Community. International Journal of Academic Research, 7(Vol. 7. No. 3. May, 2015).

Aswan, A., Agustang, A., \& Idkhan, A. M. (2022). Accountability in Health care Services: A Study at Community Lung Health Care Center of Makassar, Indonesia. Jurnal Ilmiah Ilmu Administrasi Publik, 12(1), 1-8. 
Azis, F., Idris, R., \& Agustang, A. (2017). Involution Fisheries: Post-Study Model of National Program in Integrated Movement at Community Fishermen's Village Development Arungkeke, Jeneponto. Mediterranean Journal of Social Sciences, $8(1 \quad$ SE-Articles $), 441$. https://www.richtmann.org/journal/index.php/mjss/article/view/9713

Badwi, A., Agustang, A., \& Adam, A. (2018). Individual Cognitive Dissonance in Society on Condom (A Sociology of Health Study in Makassar City). IOSR Journal Of Humanities And Social Science (IOSR-JHSS), 23(Issue 8, Ver. 7), 14-19.

Baharuddin, B., \& Agustang, A. (2022). Teacher's Strategy for Increasing Students' Creative Thinking Ability Through Open-Ended Learning in Elementary Schools. Jurnal Etika Demokrasi, 7(1), 98-108.

Djalante, A., Agustang, A., Tahmir, S., \& Sahabuddin, J. (2018). A Disadvantaged Tribe in Bajoe Village, Bone Regency: A Phenomenological Research on Bajo Tribe's Social Life in Bone Regency, South Sulawesi. IOSR Journal Of Humanities And Social Science (IOSR-JHSS).

Djamaluddin, M., Agustang, A., Idkhan, A. M., \& Rifdan. (2021). Pengaruh Implementasi Corporate Social Responsibility PT. Vale Terhadap Kesejahteraan Hidup Masyarakat. Journal Governance and Politics (JGP), 1(2 SE-Articles). https://jurnal.iyb.ac.id/index.php/jgp/article/view/200

Djamaluddin, M., Agustang, A., \& Muhammad Idkhan, A. (2022). Implementasi Program Raskin Di Kelurahan Bukit Harapan Kecamatan Soreang Kota Parepare. JISIP (Jurnal Ilmu Sosial Dan Pendidikan), 6(1), 2210-2217.

Dody May Putra Agustang, A., \& Agustang, A. (2020). Culture Of Shame-Heart And Social Solidarity Of Kaitetu People Central Maluku District, Indonesia. INTERNATIONAL JOURNAL OF SCIENTIFIC \& TECHNOLOGY RESEARCH, 9, 2. www.ijstr.org

Erni, E., \& Agustang, A. (2021). Pengaruh Teman Sebaya Terhadap Perilaku Bolos di Kalangan Peserta Didik SMK Handayani Makassar. Pinisi Journal of Sociology Education Review, 1(1), 97-102.

Fajrin, S. N., Oruh, S., \& Agustang, A. (2022). Makna Simbolik Ritual Mabbaca-Baca di Kelurahan Ujung Tanah Kecamatan Cenrana Kabupaten Bone. Equilibrium: Jurnal Pendidikan, 10(1), 5762.

Haerul, H., Agustang, A., Idhan, A. M., \& Rifdan, R. (2021). Online Learning Challenges in School. Jurnal Office, 7(2), 215-224.

Hardiyanti, A., Oruh, S., \& Agustang, A. (2022). The Influence of Parents' Social Status and Economic Conditions on Social Studies Learning Achievement of Elementary School Students 25 Madello Soppeng regency. Jurnal Etika Demokrasi, 7(1), 208-218.

Hariani, H., Oruh, S., J, A. H., \& Mustari, N. (2021). Gambaran Pola Asuh Anak Pada Ibu yang Bekerja di Kelurahan Karang Anyar Kota Makassar. Media Keperawatan: Politeknik Kesehatan Makassar, 12(1), 1. https://doi.org/10.32382/jmk.v12i1.2201

Harman, H., \& Agustang, A. (2020). Perubahan Sosial Masyarakat Permandian Wae Tuo Desa Wae Tuo Kecamatan Kajuara Kabupaten Bone. Jurnal Sosialisasi: Jurnal Hasil Pemikiran, Penelitian Dan Pengembangan Keilmuan Sosiologi Pendidikan, 2, 1-7.

Hidayat, S., Agustang, A., \& Pertiwi, N. (2022). The Effect of Land Use and Traffic Performance on Urban Air Quality in the Maminasata Peri-Urban Area. Budapest International Research and Critics Institute (BIRCI-Journal): Humanities and Social Sciences, 5(1), 2918-2932.

Irwan, I., \& Agustang, A. (2021). Strategi Keberdayaan Masyarakat Menuju Desa Wisata Berbasis Masyarakat Yang Berkelanjutan. Seminar Nasional LP2M UNM.

Ismail, L., Idris, R., \& Agustang, A. (2022). Chinese and Non-Chinese Relationships in Inclusivity. International Conference on Social, Economics, Business, and Education (ICSEBE 2021), 1016. https://doi.org/10.2991/aebmr.k.220107.003

Ismanto, Agustang, A., \& Idkhan, A. M. (2021). Pengaruh Kompensasi Finansial Terhadap Produktivitas Kerja Karyawan Pada PT PLN (PERSERO) Rayon Makassar Barat. Journal Governance and Politics (JGP), $1(2 \quad$ SE-Articles). https://ejournal.iyb.ac.id/index.php/jgp/article/view/202 
Jumadi, Nurlela, Agustang, A., \& Darman. (2020). Social Actions of Galla Actors in the Kaemba Maros Traditional Village Community Sulawesi Selatan. 3rd International Conference on Social Sciences (ICSS 2020), 748-753.

Kubangun, N. A., Agustang, A., Adam, A., \& Dody May Agustang, A. (2020). The Patro n Client Relationship Patterns In Siwa Lima Fishermen Community Aru Islands District Maluku, Indonesia. INTERNATIONAL JOURNAL OF SCIENTIFIC \& TECHNOLOGY RESEARCH, $9(2), 74-77$.

Kubangun, N., Agustang, A., \& Adam, A. (2020). Subaltern and Network Strategy Towards Fishermen Community in Aru Islands District. 3rd International Conference on Social Sciences (ICSS 2020), 585-588.

Kurniati, A., \& Agustang, A. (2022). Buton Cultural Potential in Curriculum Policy Development of Early Childhood Education Unit in Baubau City. Jurnal Etika Demokrasi, 7(1), 148-159.

Machmuddin, H., Oruh, S., \& Agustang, A. (2020). Primary Health Services in The Perspective of Participatory Governance. OSF Preprints.

Machmuddin, H., Oruh, S., \& Agustang, A. (2021). Primary Health Services in The Perspective of Participatory Governance. In academia.edu (Issue https://d1wqtxts1xzle7.cloudfront.net/64).

Mahendra, R., Agustang, A., Idkhan, A. M., \& Rifdan, R. (2021). Analisis Kinerja Aparatur Sipil Negara Dalam Pelayanan Publik. JISIP (Jurnal Ilmu Sosial Dan Pendidikan), 5(4).

Mahriadi, N., Agustang, A., Muh Andi, I., \& Rifdan. (2021). Korupsi Dana Desa Problematika Otonomi Desa Dalam Undang Undang Nomor 6 Tahun 2014 Tentang Desa. Publik: Manajemen Sumber Daya Manusia, Administrasi Dan Pelayanan Publik, 8(2), 324-336.

Mallappiang, N., Agustang, A., \& Idkhan, A. M. (2021). Keberadaan Humas Dalam Menunjang Tridharma Perguruan Tinggi Universitas Indonesia Timur Makassar. Journal Governance and Politics (JGP), 1(2), 134-148.

Mansur, Agustang, A., Muhammad Idhan, A., Kadir, Y., \& Nuna, M. (2021). Perencanaan Partisipatif Pemerintah Desa dan Masyarakat dalam Mengelola APBDES. Publik: Manajemen Sumber Daya Manusia, Administrasi Dan Pelayanan Publik, 8(2), 349-362.

Mario, M., Oruh, S., \& Agustang, A. (2021). Pola Relasi: Kontrak Radikalisme Terhadap Perempuan Milenial. Jurnal Sosialisasi: Jurnal Hasil Pemikiran, Penelitian Dan Pengembangan Keilmuan Sosiologi Pendidikan, 8, 72-86.

Marsuki, N. R., Oruh, S., \& Agustang, A. (2022). Youth Apathy in Political Contest: A Case Study in the 2020 Gowa Regency Head Election. Jurnal Etika Demokrasi, 7(1), 73-82.

Masita, M., \& Agustang, A. (2020). Pergeseran Pemaknaan Perayaan Tradisi Saiyyang Pattu'duq di Tinambung Polewali Mandar. Phinisi Integration Review, 3(2), 173-178.

Mawarni, I. S., \& Agustang, A. (2022). KONSTRUKSI SOSIAL MASYARAKAT TERHADAP REALITAS SOSIAL TRADISI SI SEMBA'DI ERA GLOBALISASI (Studi penelitian di Daerah Kandeapi Tikala, Toraja Utara). Pinisi Journal of Sociology Education Review, 1(2), 110.

Mithhar, M., \& Agustang, A. (2021). Distorsi Pendidikan Karakter Siswa Dalam Pendidikan Jarak Jauh Pada Era Pandemi Covid-19 Di Kabupaten Majene, Indonesia. Seminar Nasional LP2M $U N M$.

Mufidah, N. F., \& Agustang, A. (2020). Studi Sosiologi Pernikahan Mubarak di Pondok Pesantren Hidayatullah Makassar. Jurnal Sosialisasi: Jurnal Hasil Pemikiran, Penelitian Dan Pengembangan Keilmuan Sosiologi Pendidikan, 1, 1-8.

Muhtar, M., \& Agustang, A. (2022). Performance Analysis Of Civil Servants At The Department Of Education, Youth And Sport, Mamuju Regency, West Sulawesi. Jurnal Etika Demokrasi, 7(1), $122-135$.

Muis, Agustang, A., Muh Andi, I., \& Rifdan. (2021). Strategi Pemerintah Aceh dalam Mengedepankan Undang-Undang Pemerintah Aceh. Publik: Manajemen Sumber Daya Manusia, Administrasi Dan Pelayanan Publik, 8(2), 337-348. 
Muis, I., Agustang, A., \& Adam, A. (2020). Lansia Miskin: Demografi Sosial, Distribusi Pekerjaan, Masalah Kesehatan \& Perlindungan Sosial. Asian Journal of Social Sciences \& Humanities.

Mustadjar, M., \& Agustang, A. (2020). Pergeseran Pola Interaksi Sosial (Studi Pada Masyarakat Banggae Kabupaten Majene). Phinisi Integration Review, 3(2), 138-149.

Nasrullah, M., Agustang, A., \& Idhan, A. M. (2021). Utilization of Information Technology at the Mangarabombang District Office. Jurnal Ad'ministrare, 8(1), 339-346.

Nugroho, C., Agustang, A., \& Pertiwi, N. (2022). Dinamika Pertumbuhan Kawasan Permukiman Kota Jambi. Jurnal Ilmiah Mandala Education (JIME).

Nur, S., Andi Agustang, \& Arlin Adam. (2020). Uninhabitable Home: Portraits of Poverty in Cities. Indonesian Journal of Social and Environmental Issues (IJSEI), 1(3 SE-), 234-238. https://doi.org/10.47540/ijsei.v1i3.81

Nursafitra, M., Agustang, A., Idkhan, A. M., \& Annas, A. (2022). Kinerja Layanan Sekretariat Dewan Perwakilan Rakyat Daerah (DPRD) Kabupaten Bulukumba. JISIP (Jurnal Ilmu Sosial Dan Pendidikan), 6(1).

Nursafitra, M., Agustang, A., Idkhan, A. M., \& Nurwiwiana. (2021). Pengaruh Disiplin Kerja dan Komitmen Organisasi Terhadap Kinerja Pegawai di Kantor Dinas Kependudukan dan Pencatatan Sipil Kabupaten Enrekang. Journal Governance and Politics (JGP), 1(2 SEArticles). https://jurnal.iyb.ac.id/index.php/jgp/article/view/203

Oruh, S. (2021a). Analisis faktor Keaktifan Kader dalam Kegiatan Posyandu. Jurnal Ilmiah Kesehatan Sandi Husada, 10(1), 319-325.

Oruh, S. (2021b). Kau Mau Kemana (Refleksi Sosiologis terhadap Integritas Upaya Kesehatan Jiwa). OSF Preprints. https://doi.org/10.31219/osf.io/ut6jq

Oruh, S. (2021c). Literatur Review: Kebijakan dan Strategi Pemberdayaan Masyarakat Dalam Menurunkan Angka Kematian Ibu dan Bayi. Preventif: Jurnal Kesehatan Masyarakat, 12(1), 135-148. https://doi.org/10.22487/preventif.v12i1.297

Oruh, S., \& Agustang, A. (2019a). Pengaruh Pengetahuan Keluarga, Stigma Masyarakat dan Kepatuhan Minum Obat Terhadap Kekambuhan Penyakit Gangguan Jiwa di Kota Makassar. OSF Preprints.

Oruh, S., \& Agustang, A. (2019b). Pengaruh Pengetahuan Keluarga, Stigma Masyarakat dan Kepatuhan Minum Obat Terhadap Kekambuhan Penyakit Gangguan Jiwa di Kota Makassar. OSF Preprints, 53(9). https://doi.org/10.1017/CBO9781107415324.004

Oruh, S., \& Agustang, A. (2022a). A Study Of Sociology On Outsourcing Practice. OSF Preprints.

Oruh, S., \& Agustang, A. (2022b). Etnomedik Pada Masyarakat Bugis. OSF Preprints.

Oruh, S., \& Agustang, A. (2022c). Quality of Basic Health Services in Governance Perspective. OSF Preprints.

Oruh, S., Agustang, A., \& Bagu, A. A. (2020). Kejadian Heropnam Gangguan Jiwa dan Faktor yang Mempengaruhi Pada Rumah Sakit Khusus Daerah Dadi Provinsi Sulawesi Selatan. OSF Preprints.

Oruh, S., \& Oruh, S. (2021). Strategi Pengembangan Sumber Daya Masyarakat Kepulauan yang Unggul Menuju Society 5.0. OSF Preprints. https://doi.org/10.31219/osf.io/etqc9

Oruh, S., Oruh, S., \& Agustang, A. (2022). Pengetahuan Keluarga, Stigma Masyarakat dan Kepatuhan Minum Obat Pengaruhnya Terhadap Kekambuhan Penyakit Gangguan Jiwa di Kota Makassar. OSF Preprints. https://doi.org/10.31219/osf.io/vd7f2

Oruh, S., Theresia, M., \& Agustang, A. (2019). Kesejahteraan Psikologis. Researchgate.Net.

P Resky, A., Agustang, A., Muh Andi, I., \& Lambali, S. (2021). Implementasi Inovasi Kebijakan Program (SPP) Simpan Pinjam Perempuan di Kecamatan Tanasitolo Kabupaten Wajo. Publik: Manajemen Sumber Daya Manusia, Administrasi Dan Pelayanan Publik, 8(2), 306-323.

Rachim, A., Lolo, T. R. A., \& Agustang, A. (2017). Relations Authority. OSF Preprints.

Rahmansah, Agustang, A., \& Pertiwi, N. (2022). Perilaku Masyarakat Memelihara Lingkungan Pada 
Kompleks Perumahan Tipe Besar Di Kabupaten Soppeng. Jurnal Ilmiah Mandala Education (JIME), 8(1), 675-681.

Rajab, M. A., Oruh, S., \& Agustang, A. (2021). Persepsi Masyarakat Lokal terhadap Ekowisata Mangrove Kuri Caddi Desa Nisombalia Kabupaten Maros. Pepatudzu: Media Pendidikan Dan Sosial Kemasyarakatan, 17(2), 166-172.

Rasyid, R., Agustang, A., Agustang, A. T. P., Bastiana, B., \& Najamuddin, N. (2020). Analisis Faktor Yang Mempengaruhi Status Kemiskinan Rumah Tangga Pada Wilayah Central Bussiness District (CBD) di Kota Makassar. Majalah Geografi Indonesia, 34(1), 43-52.

Reskiawan, M. M. N., \& Agustang, A. (2022). Sistem Sekolah Berasrama (Boarding School) dalam Membentuk Karakter Disiplin di MAN 1 Kolaka. Pinisi Journal of Sociology Education Review, 1(2), 125-133.

Sahabuddin, A., Agustang, A., \& Idkhan, A. M. (2022). Community Satisfaction with the Services of DPRD Members in Bantaeng Regency. Jurnal Ilmiah Ilmu Administrasi Publik, 12(1), 9-24.

Sahabuddin, E., Agustang, A., Manda, D., \& Oruh, S. (2020a). Partisipasi Sosial Dalam Pemenuhan Activity Daily Living (Adl) Orang Dengan Gangguan Jiwa Di Kota Makassar. Phinisi Integration Review, 3(2).

Sahabuddin, E., Agustang, A., Manda, D., \& Oruh, S. (2020b). Partisipasi Sosial Dalam Pemenuhan Activity Daily Living (Adl) Orang Dengan Gangguan Jiwa Di Kota Makassar. Phinisi Integration Review, 3(2), 290. https://doi.org/10.26858/pir.v3i2.14922

Saidang, S., Oruh, S., \& Agustang, A. (2022). Resistensi Mahasiswa Terhadap Pembelajaran Online Pada Masa Pandemi. Equilibrium: Jurnal Pendidikan, 10(1), 16-23.

Sanusi, D., Agustang, A., \& Idkhan, A. M. (2022). Factors Affecting the Performance of State Civil Services in Makassar City Social Services Post Covid 19 Pandemic. Jurnal Ilmiah Ilmu Administrasi Publik, 12(1), 25-34.

Sari, R. P., \& Agustang, A. (2022). PERAN GANDA IBU RUMAH TANGGA (Studi Kasus Pada Tukang Cuci Mobil/Motor). Pinisi Journal of Sociology Education Review, 1(2), 106-113.

Suardi, Agustang, A., \& Jumadi. (2021). Domination of The Power of Quality and Quantity of State School Education Against Private Schools as Factors Causing Symbolic Violence of Students in Bantaeng District. PROCEEDING 1st INTERNATIONAL CONFERENCE (On Health, Education, and Computer Science Technology), 1(pertama), 246-259.

Suardi, Agustang, A., \& Jumadi. (2020). The Symbolic Violence Towards Private School Students Through The Frame Stereotype In Bantaeng District Of Indonesia. The International Conference on Innovations in Social Sciences and Education, 578-588.

Sumai ${ }^{1}$, S., Agustang, A., Adam, A., \& Obie, M. (2020). Resilience in Children of Drug Abuse Families: A Case in Pattingalloang, Makassar City, Indonesia. EAS Journal of Humanities and Cultural Studies.

Suparman, Oruh, S., \& Agustang, A. (2021). Dinamika Sosial Kelompok Tani (Studi Kasus Petani Bawang Merah Desa perangian Kecamatan Baraka Kabupaten Enrekang). JIIP-Jurnal Ilmiah Ilmu Pendidikan, 4(6), 406-414.

Syarifuddin, S., Oruh, S., \& Agustang, A. (2022). Dynamics of Zonation System Implementation at Senior High School 9 Gowa. Jurnal Etika Demokrasi, 7(1), 52-61.

Syukurman, S., Agustang, A., \& Adam, A. (2020). Peluang dan Tantangan Lembaga Pendidikan Islam (Ditinjau dari Sosiologi Agama di Desa Doridungga). EDU SOCIATA (Jurnal Pendidikan Sosiologi), 3(2), 71-87.

Tabo, S., Agustang, A., Idkhan, A. M., Nuna, M., \& Mobonggi, R. (2021). Analisis Proses Pemutahiran Daftar Pemilih Dalam Daftar Pemilih Tetap (DPT) Pada Pemilu Tahun 2019 Di Kabupaten Gorontalo. Jurnal Sosio Sains, $7(2$ SE-Articles). https://doi.org/10.37541/sosiosains.v7i2.632

Tenri Awaru, A. O., Idris, R., \& Agustang, A. (2018). Sexual Education at High School Sinjai East. Proceedings of the 1st International Conference on Social Sciences (ICSS 2018). https://doi.org/https://doi.org/10.2991/icss-18.2018.196 
Thamrin, H., Agustang, A., Adam, A., \& Alim, A. (2021). Disrupsi Modal Sosial Stunting di Sulawesi Selatan, Indonesia (Studi Kasus Pada Keluarga 1000 HPK di Kabupaten Bone dan Enrekang). Seminar Nasional LP2M UNM.

Umasangaji, N. K., Agustang, A., Adam, A., \& Alim, A. (2021). Dampak Pandemi Covid-19 dan Pembelajaran Daring di Kampung Atas Air Balikpapan. Seminar Nasional LP2M UNM.

Wardah, S., Salman, D., Agustang, A., \& Fahmid, I. M. (2017). The Contestation of Organic and Non-Organic Agricultural Knowledge in Sustainable Agriculture. Mediterranean Journal of $\begin{array}{llll}\text { Social Sciences, } & 8(2 & \text { SE-Articles }), & \end{array}$ https://www.richtmann.org/journal/index.php/mjss/article/view/9883

Wihdania, W., \& Agustang, A. (2020). Pernikahan Tolotang Di Kelurahan Amparita Kecamatan Tellu Limpoe Kabupaten Sidenreng Rappang. Phinisi Integration Review, 3(2), 165-172.

Yunita, I., \& Agustang, A. (2022). Ketidakmerataan Bantuan Langsung Tunai Dimasa Pandemi Covid-19 Pada Masyarakat Kurang Mampu di Desa Carawali Kabupaten Sidrap. Pinisi Journal of Sociology Education Review, 1(2), 181-191.

Yusmuliadi, Y., \& Agustang, A. (2021). Peranan Osis dalam Membentuk Karakter Peduli Sosial Siswa di SMA Negeri 3 Barru. Pinisi Journal of Sociology Education Review, 1(1), 44-53. 